\title{
Fungal Metabolite Sulfamisterin Suppresses Sphingolipid Synthesis through Inhibition of Serine Palmitoyltransferase ${ }^{\dagger}$
}

\author{
Akiko Yamaji-Hasegawa, ${ }^{\ddagger}$ Atsushi Takahashi, ${ }^{\S}$ Yasuyuki Tetsuka, ${ }^{\S}$ Yukiko Senoh,,${ }^{\ddagger}$ and Toshihide Kobayashi ${ }^{*}, \ldots, \|$ \\ RIKEN, 2-1 Hirosawa, Wako-shi, Saitama 351-0198, Japan, Hokko Chemical Industry Company, Limited, 2165 Toda, \\ Atsugi-shi, Kanagawa 243-0023, Japan, and INSERM U585, INSA (Institut National des Sciences Appliquees)-Lyon, \\ 20 Avenue Albert Einstein, 69621 Villeurbanne, France
}

Received July 2, 2004; Revised Manuscript Received October 17, 2004

\begin{abstract}
Sphingolipids and their metabolites are known to modulate various cellular events including proliferation, differentiation, and apoptosis. Serine palmitoyltransferase (SPT) is the enzyme that catalyzes the first step of the biosynthesis of all sphingolipids. Here, we report that a newly identified antibiotic, sulfamisterin, derived from the fungus Pycnidiella sp., is a specific inhibitor of SPT. The chemical structure of sulfamisterin resembles both that of sphingosine as well as a potent inhibitor of SPT, ISP-1 (myriocin). Sulfamisterin inhibited SPT activity with $\mathrm{IC}_{50}=3 \mathrm{nM}$ in a cell-free lysate prepared from Chinese hamster ovary $(\mathrm{CHO})$ fibroblasts. Sulfamisterin markedly inhibited the biosynthesis of sphingolipids in living $\mathrm{CHO}$ cells and in yeast Saccharomyces cerevisiae as monitored by radioactive precursors. Unlike the cell-free experiments, $10 \mu \mathrm{M}$ sulfamisterin was required for complete inhibition of sphingolipid biosynthesis in intact cells. We also synthesized a series of structural analogues of sulfamisterin and examined their activities both in cell-free and in living cell systems.
\end{abstract}

Sphingolipids are major plasma membrane lipid constituents in eucaryotic cells. Accumulating evidence indicates important roles for sphingolipids and their metabolites in cellular homeostasis. Ceramides and sphingosine that are produced via catabolism of sphingolipids are known as lipid messengers and are reported to modulate various cellular events including proliferation, differentiation, and apoptosis $(1-3)$.

The early steps of the sphingolipid biosynthetic pathway are conserved from fungi to mammals (4). The first step is the condensation of serine and palmitoyl CoA. This reaction is catalyzed by serine palmitoyltransferase $(\mathrm{SPT})^{1}$ [EC 2.3.1.50] $(5,6)$. This enzyme belongs to a family of pyridoxal 5 -phosphate-dependent enzymes and is reported to localize at the endoplasmic reticulum in mammalian cells (7). The product, 3-ketodihydrosphingosine, is further metabolized to dihydrosphingosine followed by the formation of ceramide (mammals) or phytoceramide (fungi) (Figure 1). SPTdeficient yeast Saccharomyces cerevisiae strains $(8-10)$ and

\footnotetext{
† This work was supported by Grants from RIKEN Frontier Research System and Chemical Biology Research Project of RIKEN and Grantsin-Aid for Scientific Research 14370753 and 16044247 (to T.K.) and 13771400 and 15790063 (to A.Y.-H.) from the Ministry of Education, Culture, Sports, Science, and Technology of Japan. A.Y.-H. was a special postdoctoral fellow of RIKEN.

* To whom correspondence should be addressed: RIKEN, 2-1, Hirosawa, Wako-shi, Saitama 351-0198, Japan. Telephone: +81-48467-9612. Fax: +81-48-467-8693. E-mail: kobayasi@riken.jp.

RIKEN.

$\S$ Hokko Chemical Industry Company.

"INSA.

${ }^{1}$ Abbreviations: SPT, serine palmitoyltransferase; TLC, thin-layer chromatography; CHO, Chinese hamster ovary; PDMP, 1-phenyl-2decanoylamino-3-morpholino-1-propanol; IPC, inositol phosphorylceramide; MIPC, mannosylinositol phosphorylceramide; $\mathrm{M}(\mathrm{IP})_{2} \mathrm{C}$, mannosyldiinositol diphosphorylceramide.
}

a mammalian cell mutant (11) cannot grow in the absence of an exogenous supply of sphingolipids or sphingolipid precursors, indicating that sphingolipids are essential for cellular survival.

Because SPT is a key enzyme for the regulation of sphingolipid levels in cells $(6,12)$, the specific inhibitors of SPT are useful for understanding the physiological roles of sphingolipids. Several natural and synthetic inhibitors of SPT have been reported. ISP-1 (myriocin/thermozymocidin) from a culture of fungus Isalia sinclairii is a widely used and highly selective SPT inhibitor (13). The structure of ISP-1 resembles that of sphingosine. ISP-1 inhibits sphingolipid synthesis in mammalian cells with $\mathrm{IC}_{50}$ values in the nanomolar range, while a micromolar concentration of ISP-1 is necessary for the inhibition of sphingolipid synthesis in S. cerevisiae $(13,14)$. Resistance of yeast against ISP-1 is likely because of the inactivation of ISP-1 by the recently described Sli1p protein (15). ISP-1 is also known to induce the apoptosis of cytotoxic T cells; thus, this antibiotic acts as immunosuppressant $(16,17)$. Interestingly, ISP-1-induced growth inhibition of yeast was suppressed by overexpression of protein kinase Ypk1 without significantly affecting lipid composition (14). This observation suggests that at least in yeast the principal role of sphingolipids for survival is to mediate signal transduction rather than to maintain cellular architecture.

Other SPT inhibitors have been reported. Sphingofungins isolated from two species of thermotolerant fungi, Aspergillus fumigatus and Paecilomyces variotii, and lipoxamycin from Streptomyces are antifungal compounds that inhibit SPT activity (18-20). Viridiofungins from Trichoderma viride are potent inhibitors of mammalian SPT, but they also inhibit squalene synthase in mammalian and yeast cells $(21,22)$. 


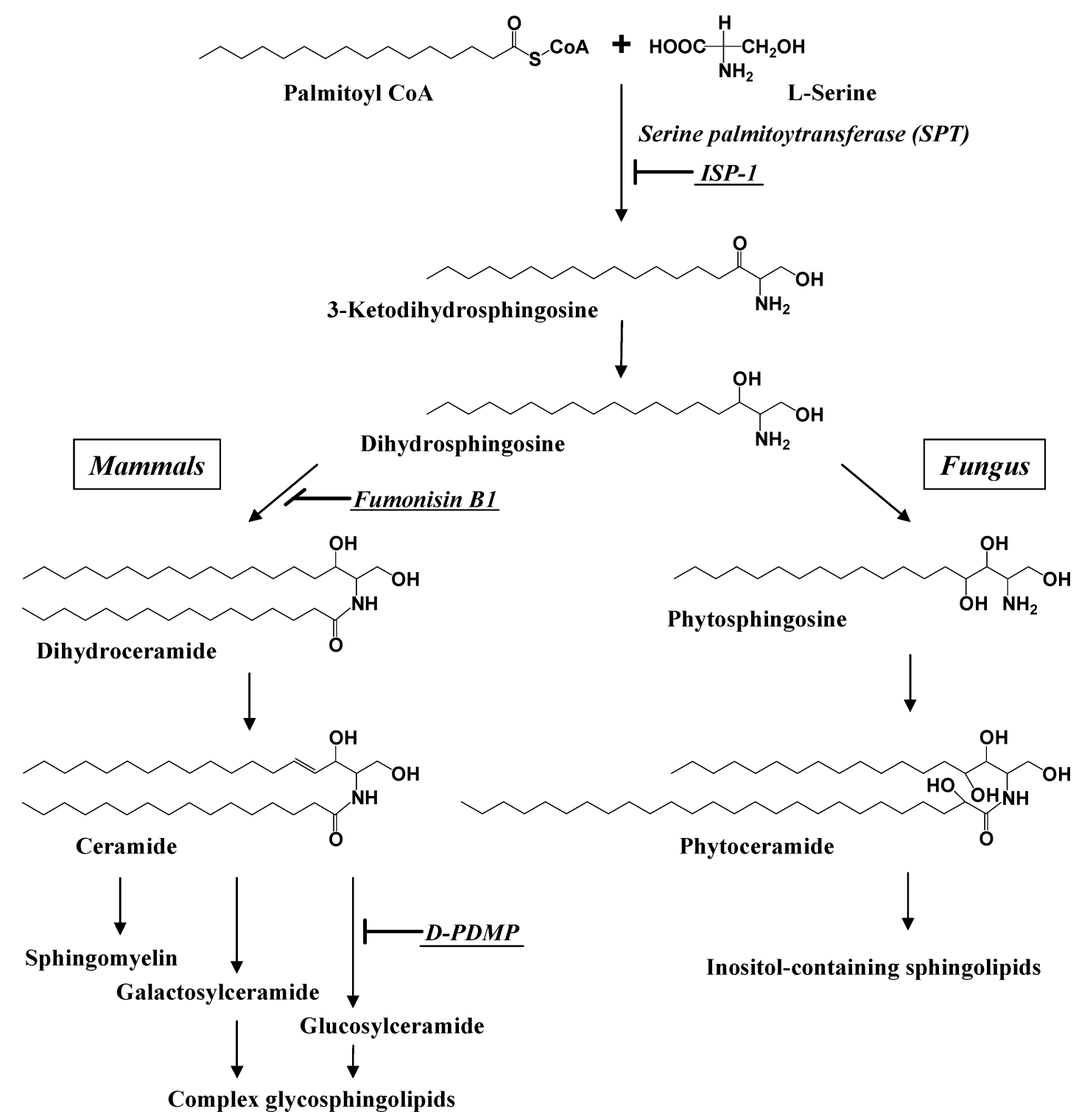

FIGURE 1: Biosynthetic pathway of sphingolipids. Inhibitors used in this paper are underlined.

L-Cycloserine and $\beta$-chloroalanine are synthetic inhibitors, which have sometimes been used to inhibit SPT in intact cells, but they are wide-range inhibitors of pyridoxal 5'phosphate-dependent enzymes $(23,24)$.

Sulfamisterin $[(2 S, 3 R)$-2-amino-2-hydroxymethyl-3-hydroxysulfonyloxy-12-oxo-octadecanoic acid] is a newly identified antibiotic derived from fungus Pycinidiella strain AB5366. In the present study, we showed that sulfamisterin inhibits SPT activity with an $\mathrm{IC}_{50}=3 \mathrm{nM}$ in a cell-free system. Sulfamisterin also inhibits sphingolipid biosynthesis in mammalian and yeast cells. We also synthesized structural analogues of sulfamisterin and examined their activities.

\section{EXPERIMENTAL PROCEDURES}

Materials. ISP-1 (myriocin), fumonisin B1, and phytosphingosine were purchased from Sigma (St. Louis, MO). D-PDMP (1-phenyl-2-decanoylamino-3-morpholino-1-propanol) and dihydrosphingosine were from Matreya, Inc. (Pleasant Gap, PA). L- $\left[{ }^{3} \mathrm{H}\right]$ Serine and L- $\left[{ }^{14} \mathrm{C}\right]$ serine were from Perkin-Elmer Life Sciences, Inc. (Boston, MA). [3- $\left.{ }^{3} \mathrm{H}\right]-\mathrm{D}-$ Erythro-sphingosine and $\left[4,5-{ }^{3} \mathrm{H}\right]$ dihydrosphingosine were from American Radiolabeled Chemical, Inc. (St. Louis, MO).
Preparation of Sulfamisterin and its Derivatives. The chemical structures of sulfamisterin and its synthetic derivatives are displayed in Figure 2. The production organism of sulfamisterin was classified as a strain belonging to the genus Pycnidiella from its taxonomic features (data not shown) and designated as Pycnidiella sp. AB5366. Cells were grown in a medium consisting of $1.0 \%$ glucose, $1.5 \%$ dextrin, $1.0 \%$ yeast extract, $1.0 \%$ malt extract, $0.5 \% \quad \mathrm{KH}_{2} \mathrm{PO}_{4}, 0.3 \%$ $\mathrm{MgSO}_{4} \cdot 7 \mathrm{H}_{2} \mathrm{O}$, and $0.3 \% \mathrm{CaCO}_{3}$. A loopful of slant culture of strain AB5366 was inoculated into Erlenmeyer flasks (500 $\mathrm{mL}$ ) containing $100 \mathrm{~mL}$ of the fermentation medium and cultured at $25^{\circ} \mathrm{C}$ for 5 days on a rotary shaker $(180 \mathrm{rpm})$. Sulfamisterin was isolated from $10 \mathrm{~L}$ of the fermentation broth. The culture filtrate was applied to Duolite A113 plus column chromatography (Cl-form, $500 \mathrm{~mL}$, Sumitomo Chemical Co., Ltd., Tokyo, Japan). The column was washed with $2 \mathrm{~L}$ of water, $2 \mathrm{~L}$ of $1 \mathrm{~N} \mathrm{HCl}$, and $4 \mathrm{~L}$ of water, successively. The active fractions were eluted with $0.05 \mathrm{~N}$ $\mathrm{HCl} /$ methanol $(1: 4, \mathrm{v} / \mathrm{v})$, collected, and neutralized with 5 $\mathrm{N} \mathrm{NaOH}$. The solution was concentrated to $500 \mathrm{~mL}$, adjusted to $\mathrm{pH} 3$ with $5 \mathrm{~N} \mathrm{HCl}$, and applied to Dianion HP-20 (200 $\mathrm{mL}$, Mitsubishi Chemical Corporation, Toyko, Japan). The 


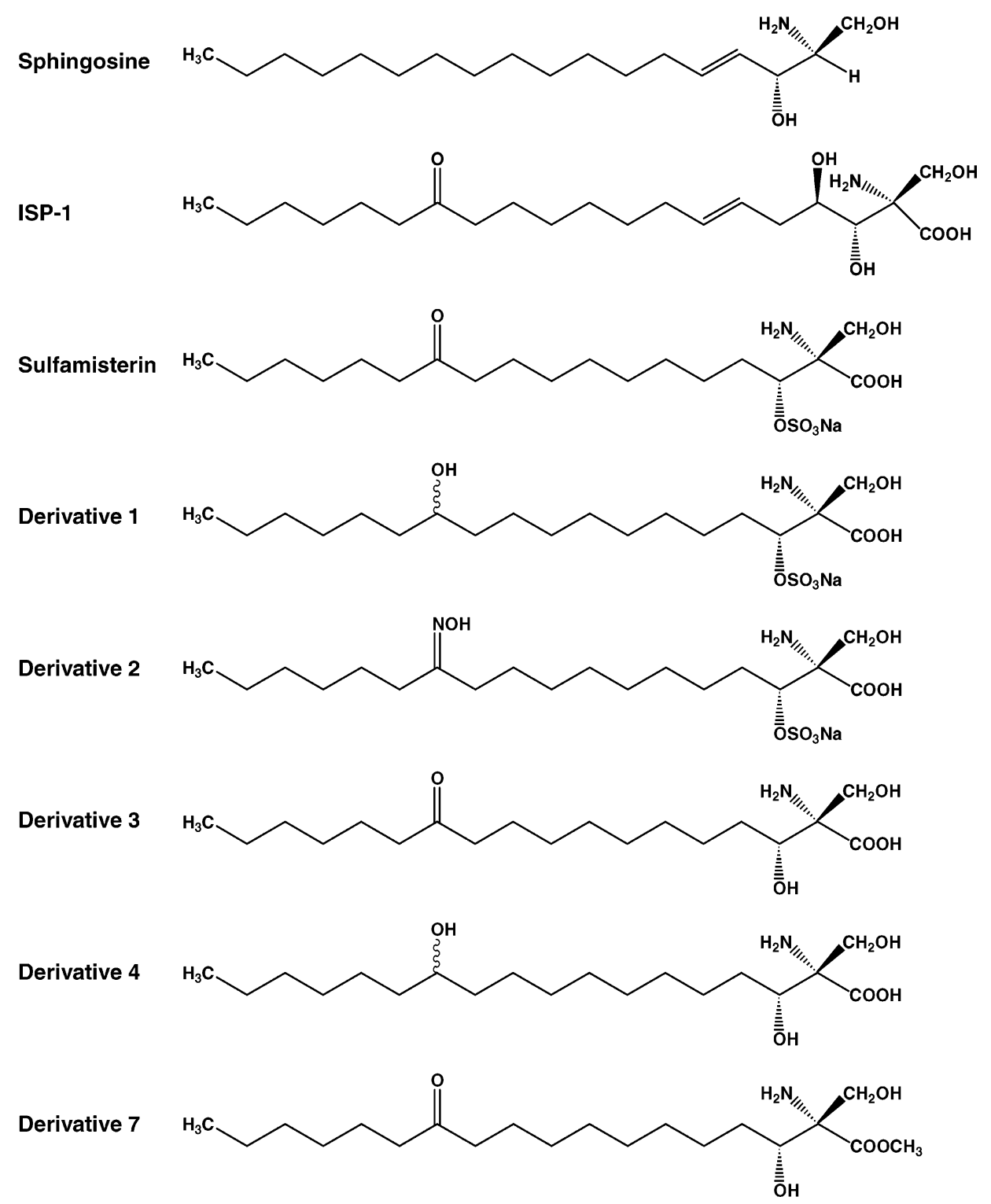

FIGURE 2: Structures of sphingosine, ISP-1, sulfamisterin, and its derivatives.

column was washed with $400 \mathrm{~mL}$ of water and $400 \mathrm{~mL}$ of water/methanol $(3: 2, v / v)$, successively. The active fractions were eluted with water/methanol $(1: 4, \mathrm{v} / \mathrm{v})$, and then the eluate was neutralized with $5 \mathrm{~N} \mathrm{NaOH}$. Further purification was carried out on Dianion CHP-20 column chromatography (100 mL, Mitsubishi Chemical Corporation) using water/ methanol $(3: 7, \mathrm{v} / \mathrm{v})$ as the eluant. The active substance thus obtained was crystallized from water/methanol $(3: 7, \mathrm{v} / \mathrm{v})$ to yield pure sulfamisterin as its sodium salt $(450 \mathrm{mg})$. The structure of sulfamisterin was determined to be monosodium salt of (2S,3R)-2-amino-2-hydroxymethyl-3-hydroxysulfonyloxy-12-oxo-octadecanoic acid by NMR, mass spectroscopic analysis, and X-ray crystallographic analysis. The details on structure elucidation will be described elsewhere.

Derivative 1 ( $\mathrm{Na}$ salt of 12-hydroxysulfamisterin) was obtained by reduction of sulfamisterin using sodium borohydride and purified by Dianion HP-20 (73\% yield). Derivative 2 ( $\mathrm{Na}$ salt of 12-hydroxylaminosulfamisterin) was obtained by oximation of sulfamisterin with hydroxylamine chrolide. The compound was purified by Dianion HP-20 to yield a white powder ( $70 \%$ yield). Derivative $3(\mathrm{HCl}$ salt of sulfamisterin desulfate) was obtained by hydrolysis of sulfamisterin with $5 \mathrm{M} \mathrm{HCl}$ (73\% yield). Derivative 4 ( $\mathrm{Na}$ salt of 12-hydroxysulfamisterin desulfate) was obtained by reduction of derivative 3 with sodium borohydride $(80 \%$ yield from derivative 3 ). Derivative 7 (methylsulfamisterin desulfate) was obtained by methylation of derivative 3 with diazomethane. The compound was purified by a column chromatography of Sephadex LH-20 (Amersham Biosciences) to yield a white powder $(40 \%$ yield from derivative $3)$. The chemical structures of these derivatives were determined by NMR, mass spectrometry, infrared absorption spectroscopy, and X-ray crystallographic analysis. All compounds were dissolved in dimethyl sulfoxide as stock solutions $(10 \mathrm{mg} / \mathrm{mL})$, except for cell-growth experiments. It was confirmed that the concentrations of dimethyl sulfoxide used did not affect the results under our experimental conditions.

Cell Cultures. The Chinese hamster ovary (CHO) cells were routinely grown on $10 \mathrm{~cm}$ dishes in Ham's F-12 medium supplemented with $10 \%$ (v/v) fetal calf serum, penicillin $\mathrm{G}$ (100 units/mL) and streptomycin sulfate (100 $\mu \mathrm{g} / \mathrm{mL}$ ) (normal medium). Cultures were maintained at 37 ${ }^{\circ} \mathrm{C}$ in a $5 \% \mathrm{CO}_{2}$ atmosphere at $100 \%$ humidity. For serum- 
free culture, nutridoma SP (Roche Diagnostics GmbH, Mannheim, Germany) was used instead of fetal calf serum.

Enzyme Assay for SPT. SPT activity was assayed by the method of Merrill with a modification (25). CHO cells were washed 3 times with ice-cold phosphate-buffered saline (PBS). A total of $0.5 \mathrm{~mL}$ of lysis buffer [50 mM Hepes ( $\mathrm{pH}$ 8.0) containing $5 \mathrm{mM}$ ethylenediaminetetraacetic acid (EDTA) and $5 \mathrm{mM}$ dithiothreitol (DTT)] was added to each dish. The cells were scraped using a rubber policeman and transferred to a test tube on ice. The cell suspension was sonicated 3 times for $5 \mathrm{~s}$ at $1-2$ min intervals on ice. Protein concentrations in cell homogenates were measured using a Bradford protein assay kit (Bio-Rad). To measure the SPT activity, $0.1 \mathrm{~mL}$ of cell homogenates were added to $0.1 \mathrm{~mL}$ of reaction buffer [20 mM Hepes (pH 8.0) containing 5 mM EDTA, 10 mM DTT, $50 \mu \mathrm{M}$ pyridoxal-5'-phosphate, $0.4 \mathrm{mM}$ palmitoyl CoA, $2 \mathrm{mM}$ L-serine, $10 \mu \mathrm{Ci}$ of $\left[{ }^{3} \mathrm{H}\right]$ serine, and sulfamisterin or ISP-1]. After incubation at $37^{\circ} \mathrm{C}$ for $20 \mathrm{~min}$ with shaking, the reaction was terminated with $0.5 \mathrm{~mL}$ of $0.5 \mathrm{~N} \mathrm{NH}_{4} \mathrm{OH}$ containing $10 \mathrm{mM} \mathrm{L}$-serine. The lipid products were extracted using the solvent system: $3 \mathrm{~mL}$ of chloroform/methanol (1: 2), $25 \mu \mathrm{g}$ of sphingosine $(1 \mathrm{mg} / \mathrm{mL}$ in ethanol) as a carrier, $2 \mathrm{~mL}$ of chloroform, and $3.8 \mathrm{~mL}$ of $0.5 \mathrm{~N} \mathrm{NH}_{4} \mathrm{OH}$. After vigorous mixing, the phases were separated by centrifugation at $2500 \mathrm{rpm}$ for $5 \mathrm{~min}$ (himac CF 8DL, Hitachi, Tokyo, Japan). The aqueous layer was removed by aspiration, and the lower chloroform layer was washed 3 times with $4.5 \mathrm{~mL}$ of water. The chloroform layer was transferred to a scintillation vial, and the solvent was evaporated under $\mathrm{N}_{2}$ gas. The radioactivity was measured with a LS6000TA liquid scintillation counter (Beckman). Nonspecific conversion of $\left[{ }^{3} \mathrm{H}\right]$ serine to chloroform-soluble species was determined by performing the assay in the absence of palmitoyl CoA. The count of the background was about one-sixth of the count of $100 \%$ activity.

Inhibition of Lipid Synthesis in CHO Cells. CHO cells on $6 \mathrm{~cm}$ dishes were treated with fumonisin B1, D-PDMP, ISP1 , or sulfamisterin before incubation with $\left[{ }^{14} \mathrm{C}\right]$ serine, $\left[{ }^{3} \mathrm{H}\right]$ sphingosine, or $\left[{ }^{3} \mathrm{H}\right]$ dihydrosphingosine $(1 \mu \mathrm{Ci} / \mathrm{mL})$ for $2 \mathrm{~h}$. Cells were washed with PBS and collected by scraping. Total lipids extracted by the method of Bligh and Dyer (26) were separated by thin-layer chromatography (TLC) using a solvent of chloroform/methanol/methyl acetate/1-propanol/ $0.25 \%$ potassium chloride $(25: 10: 25: 25: 9, \mathrm{v} / \mathrm{v})$. Radioactive lipids on TLC plates were visualized, and their relative radioactivity was determined by using a BAS2000 Bioimaging analyzer (Fujifilm, Tokyo, Japan). Lipid species of each band were identified by comparison with the standard lipids.

Analysis of Phospholipid Composition. CHO cells on 15 $\mathrm{cm}$ dishes were cultured in normal or serum-free medium containing various inhibitors for 1 or 3 days. Cells were washed with PBS and scraped using a rubber policeman. Total lipids were extracted by the method of Bligh and Dyer (26) and then separated by TLC with a solvent of chloroform/ methanol/acetic acid/formic acid (50:30:4.5:6.5, v/v). The pattern of the lipids was visualized with primuline. Silica gel containing each phospholipid was scraped, and phospholipids were extracted by the method of Bligh and Dyer. The amount of phospholipids was measured by phosphorus determination (27).
Measurement of Cell Growth. Stock solution of sulfamisterin $(2 \mathrm{mg} / \mathrm{mL})$ was prepared in PBS/distilled water (1: 5). A low concentration of salt was required to completely disperse high concentrations of sulfamisterin. $\mathrm{CHO}$ cells (5 $\times 10^{3}$ cells per well) were seeded on 24-well plates and cultured for 2 days. Then, the medium was changed to a new medium containing the indicated concentrations of sulfamisterin. After the living cells were grown for the indicated times, they were quantified using the XTT assay kit (Roche Diagnostics $\mathrm{GmbH}$ ).

Inhibition of Lipid Synthesis in S. cerevisiae. Yeast strains KMY1006a and BY4741 were cultured in SD medium (yeast nitrogen base, essential amino acids, and glucose) at $30{ }^{\circ} \mathrm{C}$. Early log-phase cultures $\left(\mathrm{OD}_{600}=0.2,2 \mathrm{~mL}\right)$ were grown for $1.5 \mathrm{~h}$ followed by an additional $1 \mathrm{~h}$ in the presence of sulfamisterin or ISP-1. Then, the cells were labeled with $\left[{ }^{3} \mathrm{H}\right]$ serine $(20 \mu \mathrm{Ci} / \mathrm{mL})$ for $3.5 \mathrm{~h}$ in the presence of inhibitors and were collected by centrifugation. The cells were washed twice with cold water and then treated with 5\% trichloroacetic acid at $4{ }^{\circ} \mathrm{C}$ for $20 \mathrm{~min}$. Lipids were extracted twice with ethanol/water/diethyl ether/pyridine/ammonia (15:15: 5:1:0.018) at $60^{\circ} \mathrm{C}$ for $15 \mathrm{~min}$. The solvents were evaporated under $\mathrm{N}_{2}$ gas. Dried lipids were subjected to mild alkaline methanolysis by addition of $0.1 \mathrm{~N}$ potassium hydroxide/ 1 $\mathrm{mL}$ of methanol at $40^{\circ} \mathrm{C}$ for $1 \mathrm{~h}$ and neutralized with $1 \mathrm{~N}$ hydrochloric acid. The lipid products were extracted with 3 $\mathrm{mL}$ of chloroform/1 mL of methanol/ $4.5 \mathrm{~mL}$ of $0.5 \mathrm{~N}$ ammonia followed by centrifugation at $2000 \mathrm{rpm}$ for $5 \mathrm{~min}$. The lower phase was washed 3 times with water and then separated by TLC with a solvent of chloroform/methanol/ 4.2 N ammonia (9:7:2, v/v). Radioactive lipids on TLC plates were visualized, and their relative radioactivities were determined using a BAS2000 Bioimaging analyzer (Fujifilm, Tokyo, Japan).

Sensitivity of S. cerevisiae to Sulfamisterin and ISP-1. Growth inhibition assays were performed to measure sensitivity to inhibitors. Yeast strains BY4741 (wild type) and $\Delta$ slil were cultured in SD medium and diluted to $\mathrm{OD}_{600}=$ 0.002 . Serial dilutions $(100 \mu \mathrm{L})$ of inhibitors in SD medium were prepared in 96-well plates, and $100 \mu \mathrm{L}$ aliquots of cells were added to each well. The plates were incubated without shaking at $30{ }^{\circ} \mathrm{C}$ for $48 \mathrm{~h}$, and the contents of each well was mixed before measuring the optical densities at $595 \mathrm{~nm}$ using a Microplate Reader model 550 (Bio-Rad). To quantify the proliferating cells, a colony-forming assay was performed.

The contents of each well was diluted 1000 times with sterile water, and $100 \mu \mathrm{L}$ aliquots of the cell suspensions were expanded on YPD agar plates (yeast extract, peptone, glucose, and $2 \%$ agar). The number of colony was counted after 2 days of incubation at $30{ }^{\circ} \mathrm{C}$.

Growth Rescue of S. cerevisiae against Sulfamisterin Using Sphingolipid Metabolites. Yeast strain BY4741 was cultured in $\mathrm{SD}$ medium and diluted to $\mathrm{OD}_{600}=0.002$. Aliquots ( $100 \mu \mathrm{L}$ ) of cells were then added to $100 \mu \mathrm{L}$ serial dilutions of dihydrosphingosine or phytosphingosine in SD medium in the absence or presence of $100 \mu \mathrm{M}$ sulfamisterin in 96-well plates. The plates were incubated without shaking at $30{ }^{\circ} \mathrm{C}$ for $48 \mathrm{~h}$, and then the colony-forming assay was performed as described above. 


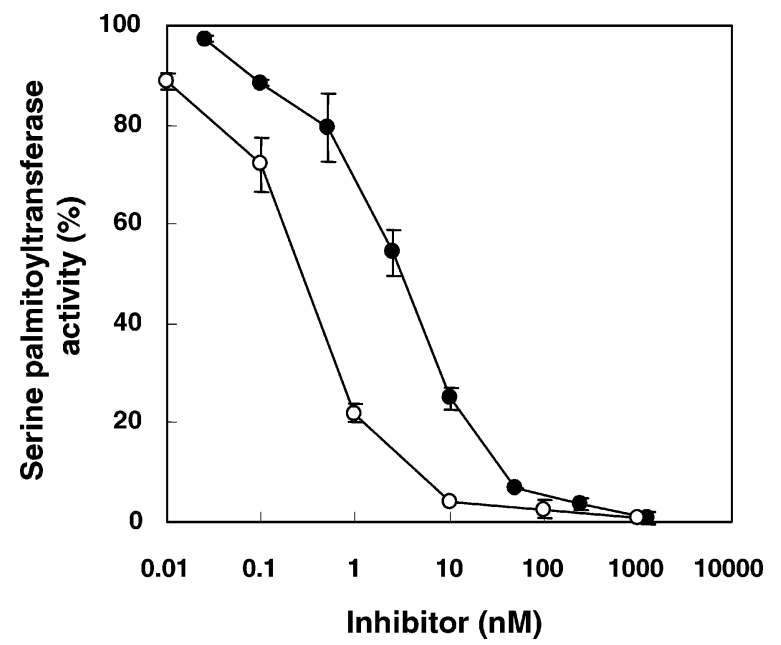

FIGURE 3: Sulfamisterin inhibited the activity of SPT in cell-free lysates. The activity of SPT in CHO lysate was measured in the presence of sulfamisterin (O) or ISP-1 (O), as described under the Experimental Procedures. SPT activity of $100 \%$ was determined by performing the assay without antibiotics. The data show the mean values \pm deviation from two independent experiments.

\section{RESULTS AND DISCUSSION}

Sulfamisterin Inhibits SPT Activity in a Cell-Free System. We have identified a new antibiotic from the fungus Pycnidiella strain AB5366. The structure of this antibiotic was determined as described in the Experimental Procedures (Figure 2). Because it has a sulfate group and the backbone structure resembles myristic acid, we designated this antibiotic "sulfamisterin". Because the structure of sulfamisterin resembles that of sphingosine as well as a potent inhibitor of SPT, ISP-1, we asked whether sulfamisterin would also inhibit SPT. In Figure 3, we tested whether sulfamisterin inhibits SPT activity using cell lysate from $\mathrm{CHO}$ cells. Sulfamisterin inhibited SPT activity of mammalian cells in a dose-dependent manner with an $\mathrm{IC}_{50}=3 \mathrm{nM}$. The activity was comparable to that of ISP-1, which inhibited SPT activity with an $\mathrm{IC}_{50}=0.3 \mathrm{nM}$.

Sulfamisterin Inhibits the Biosynthesis of Sphingolipids in Mammalian Cells. To ask whether sulfamisterin inhibits sphingolipid biosynthesis in mammalian cells, $\mathrm{CHO}$ cells were labeled with $\left[{ }^{14} \mathrm{C}\right]$ serine after treatment with sulfamisterin or various known inhibitors of sphingolipid synthesis. Radiolabeled lipids were separated by TLC, visualized (Figure 4A), and quantified (Figure 4B). $\left[{ }^{14} \mathrm{C}\right]$ Serine was incorporated into sphingolipids such as sphingomyelin, glucosylceramide, and ceramide, as well as the serine-derived phospholipids, phosphatidylserine, and phosphatidylethanolamine. Fumonisin B1 is a potent, competitive inhibitor of ceramide synthase, the enzyme that catalyzes the acylation of dihydrosphingosine in the de novo synthesis of sphingolipids (28). Fumonisin B1 inhibited biosynthesis of sphingolipids. D-PDMP is a specific inhibitor of UDPglucose:ceramide glucosyltransferase, which produces glucosylceramide (29). Because D-PDMP does not inhibit sphingomyelin synthase and ceramide synthase, only the biosynthesis of glucosylceramide was inhibited by D-PDMP. As reported, ISP-1 selectively inhibited sphingolipid synthesis. Sulfamisterin inhibited the synthesis of sphingolipids including sphingomyelin, glucosylceramide, and ceramide, whereas incorporation of $\left[{ }^{14} \mathrm{C}\right]$ serine to phosphatidylserine and phosphatidylethanolamine was not significantly affected by this antibiotic.

In Figure 4C, the dose dependency of sulfamisterin for inhibition of sphingolipid biosynthesis was studied. While $100 \mathrm{nM}$ sulfamisterin was sufficient to completely inhibit SPT activity in CHO lysate (Figure 3), $10 \mu \mathrm{M}$ sulfamisterin was required for complete inhibition of sphingolipid biosynthesis in cells. This concentration is comparable to that required for other established inhibitors such as fumonisin B1 and D-PDMP, but it is in clear contrast to the results observed for ISP-1. ISP-1 inhibited SPT both in cell lysate and intact cells with a concentration as low as $50 \mathrm{nM}$. These results suggest that compared to the cell-free assay, sulfamisterin hardly reaches the intracellular site of action when added to intact cells. The inhibitory effect of sulfamisterin on sphingolipid biosynthesis was observed rapidly and lasted for 3 days with a gradual decrease of the effect (Figure 4D). Other antibiotics in culture medium, such as penicillin G and streptomycin sulfate, did not affect the inhibitory effect of sulfamisterin on sphingolipid biosynthesis (Figure 4E).

To test that the inhibition of sphingolipid synthesis by sulfamisterin was due to the inhibition of SPT, $\left[{ }^{3} \mathrm{H}\right]-$ sphingosine (Figure 4F) and $\left[{ }^{3} \mathrm{H}\right]$ dihydrosphingosine (Figure $4 \mathrm{G}$ ), intermediary metabolites of sphingolipid synthesis, were used as precursors instead of $\left[{ }^{14} \mathrm{C}\right]$ serine. Fumonisin B1 strongly inhibited the synthesis of sphingomyelin, ceramide, and glucosylceramide. In contrast, sulfamisterin and ISP-1 did not affect the synthesis of sphingomyelin from these two precursors and slightly inhibited the synthesis of ceramide and glucosylceramide. D-PDMP inhibited only glucosylceramide synthesis and did not affect the synthesis of sphingomyelin or ceramide. Both $\left[{ }^{3} \mathrm{H}\right]$ sphingosine and $\left[{ }^{3} \mathrm{H}\right]-$ dihydrosphingosine were also incorporated into phosphatidylethanolamine probably through degradation by sphingosine kinase and sphingosine-1-phosphate lyase reactions, resulting in the formation of phosphorylethanolamine, an intermediate for phosphatidylethanolamine synthesis $(30,31)$. All inhibitors tested did not affect the synthesis of phosphatidylethanolamine. The fact that de novo synthesis of sphingolipids was inhibited only from serine but not from sphingosine and dihydrosphingosine indicates that sulfamisterin suppresses sphingolipid synthesis through the inhibition of SPT.

Phospholipid composition in $\mathrm{CHO}$ cells was analyzed after 1 or 3 days of treatment with various inhibitors including sulfamisterin (Table 1). Among the phospholipids tested, only sphingomyelin is produced through the pathway for sphingolipid biosynthesis. Sulfamisterin, ISP-1, and fumonisin B1 decreased the content of sphingomyelin. D-PDMP did not affect phospholipid composition, which is consistent with the fact that D-PDMP does not inhibit sphingomyelin synthase. When cells were cultured in normal medium containing $45 \mu \mathrm{M}$ sulfamisterin for 1 day, the content of sphingomyelin decreased to about $70 \%$ compared to the cells cultured without the inhibitor. About $70 \%$ of sphingomyelin still remained after 3 days of treatment with sulfamisterin. Inhibitors decreased sphingomyelin content more effectively when cells were cultured in serum-free medium. The content of sphingomyelin decreased to about $40 \%$ when cells were cultured in serum-free medium containing $45 \mu \mathrm{M}$ sulfamisterin only for 1 day, and sphingomyelin was further decreased after 3 days of culture. These results suggest that 
A

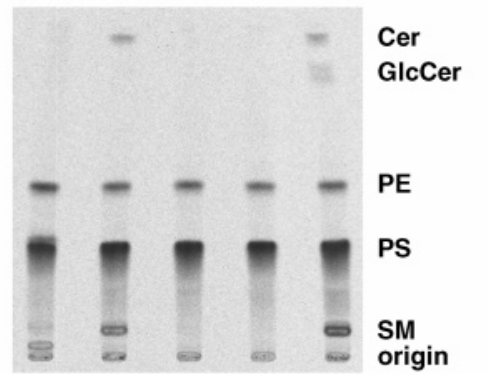

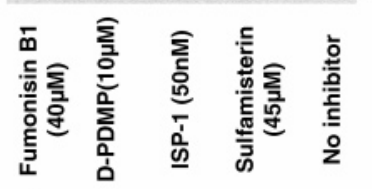
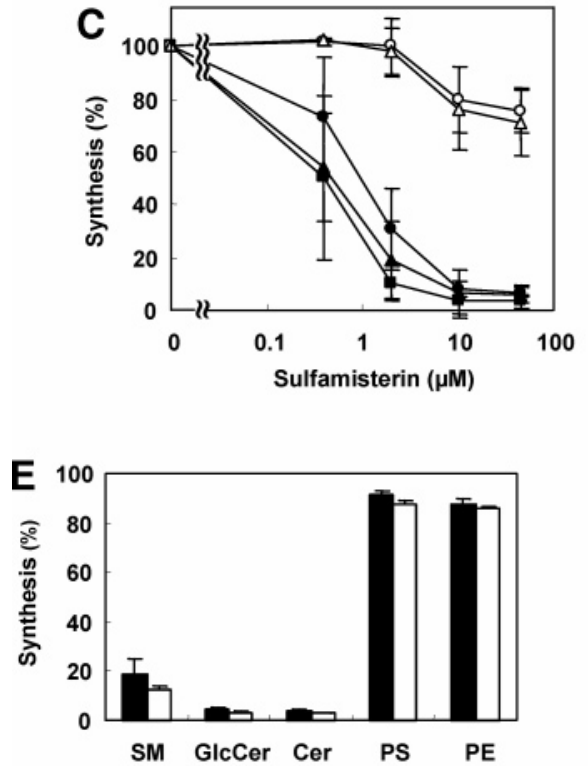

\section{B $\quad\left[{ }^{14} \mathrm{C}\right]-$ serine}
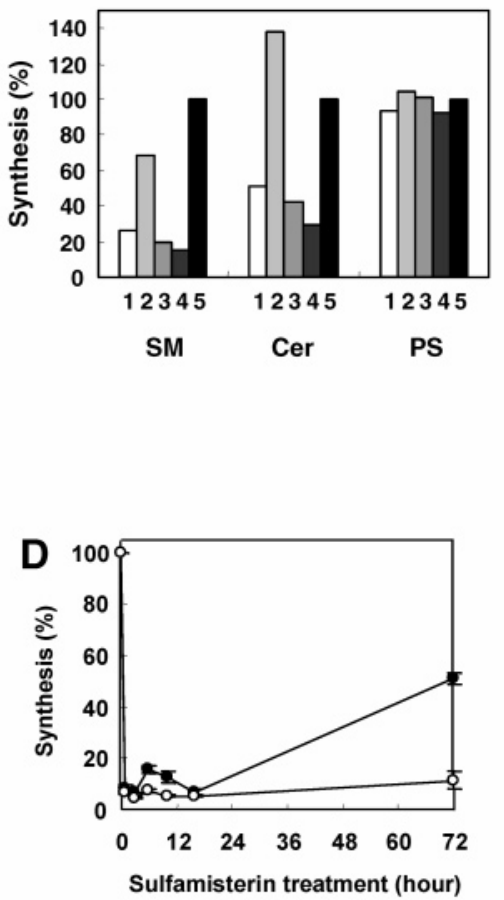

$\mathbf{F}$

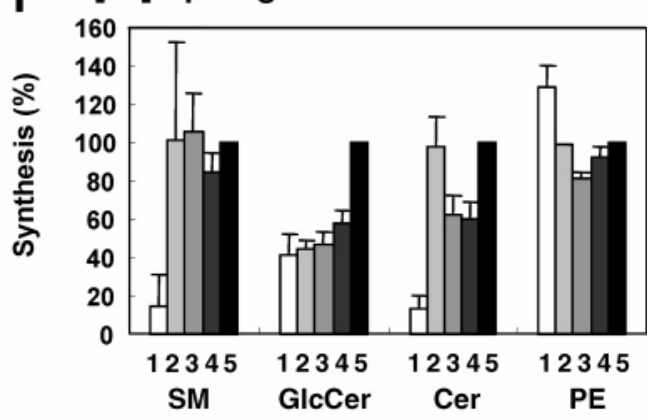

G $\quad\left[{ }^{3} \mathrm{H}\right]$-dihydrosphingosine

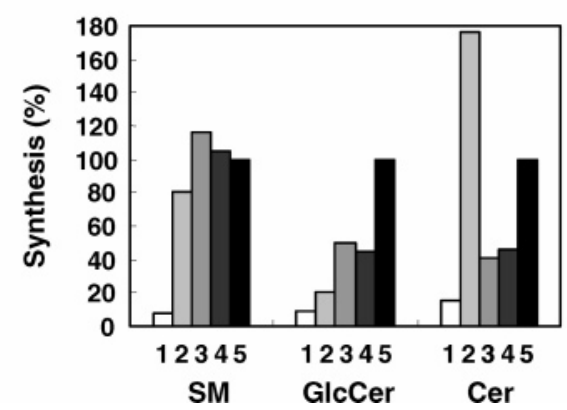

FIGURE 4: Sulfamisterin inhibited sphingolipid biosynthesis in CHO cells. (A) CHO cells, treated overnight with fumonisin B1 (40 $\mu \mathrm{M}$ ), D-PDMP $(10 \mu \mathrm{M})$, ISP-1 $(50 \mathrm{nM})$, sulfamisterin $(45 \mu \mathrm{M})$, or without inhibitors, were labeled with $\left[{ }^{14} \mathrm{C}\right]$ serine for $2 \mathrm{~h}$, and newly synthesized lipids were analyzed by TLC as described under the Experimental Procedures. SM, sphingomyelin; PS, phosphatidylserine; PE, phosphatidylethanolamine; GlcCer, glucosylceraminde; and Cer, ceramide. The band just above the origin in the fumonisin B1-treated sample was not identified. (B) Band intensity of sphingomyelin (SM), ceramide (Cer), and phosphatidylserine (PS) in A was quantified, and the percentage of each lipid synthesis was shown. The synthesized lipids in the absence of inhibitors were taken as $100 \%$. Lane 1 , fumonisin B1 (40 $\mu \mathrm{M})$; lane 2, D-PDMP (10 $\mu \mathrm{M})$; lane 3, ISP-1 (50 nM), lane 4, sulfamisterin (45 $\mu \mathrm{M})$; and lane 5, no inhibitor. (C) Dose dependence of sulfamisterin for the inhibition of sphingolipid synthesis in $\mathrm{CHO}$ cells. Cells were treated with sulfamisterin overnight, and newly synthesized lipids were analyzed as in A and B. $\mathbf{O}$, sphingomyelin; $\mathbf{\Delta}$, glucosylceramide; $\mathbf{\square}$, ceramide; $O$, phosphatidylserine; and $\triangle$, phosphatidylethanolamine. (D) Time course of the inhibition of sphingolipid biosynthesis by sulfamisterin (45 $\mu \mathrm{M})$. Cells were incubated with sulfamisterin for the indicated intervals followed by the measurement of sphingolipid biosynthesis for $2 \mathrm{~h}$ as described in the Experimental Procedures in the presence of inhibitors. -, sphingomyelin; and $\bigcirc$, ceramide. (E) Antibiotics in culture medium did not affect the activity of sulfamisterin. CHO cells were treated with $45 \mu \mathrm{M}$ sulfamisterin for $3 \mathrm{~h}$ in the presence (filled bar) or absence (blank bar) of penicillin $\mathrm{G}$ and streptomycin sulfate. (F and $\mathrm{G})$ Lipid synthesis was measured as in B using $\left[{ }^{3} \mathrm{H}\right]$ sphingosine $(\mathrm{F})$ or $\left[{ }^{3} \mathrm{H}\right]$ dihydrosphingosine $(\mathrm{G})$ as precursors. Lane 1, fumonisin B1 $(40 \mu \mathrm{M})$; lane 2, D-PDMP $(10 \mu \mathrm{M})$; lane 3, ISP-1 $(50 \mathrm{nM})$, lane 4 , sulfamisterin (45 $\mu \mathrm{M})$; and lane 5, no inhibitor. The data in $\mathrm{C}$ and $\mathrm{F}$ show the mean values \pm deviation from two independent experiments. Experiments were performed in duplicate for D and E. 
Table 1: Phospholipid Composition of CHO Cells after Treatment with Various Inhibitors ${ }^{a}$

\begin{tabular}{|c|c|c|c|c|c|c|c|}
\hline \multicolumn{8}{|c|}{ Normal Medium } \\
\hline & \multicolumn{2}{|l|}{1 day } & \multicolumn{5}{|c|}{3 days } \\
\hline & sulfamisterin $(45 \mu \mathrm{M})$ & no inhibitor & fumonisin $\mathrm{B} 1(40 \mu \mathrm{M})$ & $\operatorname{PDMP}(10 \mu \mathrm{M})$ & ISP-1 (50 nM) & sulfamisterin $(45 \mu \mathrm{M})$ & no inhibitor \\
\hline SM & 7.8 & 11.7 & 6.6 & 15.7 & 10.8 & 9.9 & 14.3 \\
\hline $\mathrm{PC}$ & 61.8 & 57.0 & 60.0 & 52.3 & 57.1 & 56.8 & 51.2 \\
\hline PI & 3.0 & 2.7 & 5.1 & 3.6 & 4.4 & 4.8 & 4.0 \\
\hline PS & 3.3 & 4.9 & 4.1 & 5.3 & 4.4 & 5.2 & 6.7 \\
\hline $\mathrm{PE}$ & 24.1 & 23.7 & 24.2 & 23.1 & 23.3 & 23.3 & 23.8 \\
\hline total & 100.0 & 100.0 & 100.0 & 100.0 & 100.0 & 100.0 & 100.0 \\
\hline \multicolumn{8}{|c|}{ Serum-Free Medium } \\
\hline & \multicolumn{2}{|l|}{1 day } & \multicolumn{5}{|c|}{3 days } \\
\hline & sulfamisterin $(45 \mu \mathrm{M})$ & no inhibitor & fumonisin $\mathrm{B} 1(40 \mu \mathrm{M})$ & $\operatorname{PDMP}(10 \mu \mathrm{M})$ & ISP-1 (50 nM) & sulfamisterin $(45 \mu \mathrm{M})$ & no inhibitor \\
\hline SM & 5.0 & 11.6 & 2.5 & 8.1 & 2.7 & 3.5 & 9.7 \\
\hline PC & 57.1 & 51.0 & 54.8 & 46.0 & 55.4 & 50.1 & 45.5 \\
\hline PI & 2.1 & 1.5 & 6.7 & 7.0 & 7.5 & 9.0 & 7.4 \\
\hline PS & 2.9 & 3.7 & 6.3 & 7.2 & 6.8 & 7.9 & 7.7 \\
\hline PE & 32.9 & 32.2 & 29.7 & 31.7 & 27.6 & 29.5 & 29.7 \\
\hline total & 100.0 & 100.0 & 100.0 & 100.0 & 100.0 & 100.0 & 100.0 \\
\hline
\end{tabular}

${ }^{a} \mathrm{CHO}$ cells were cultured in normal medium or serum-free medium containing the indicated inhibitors. After 1 or 3 days, cells were collected and the composition of phospholipids was analyzed as described in the Experimental Procedures. SM, sphingomyelin; PC, phosphatidylcholine; PI, phosphatidylinositol; PS, phosphatidylserine; and PE, phosphatidylethanolamine.

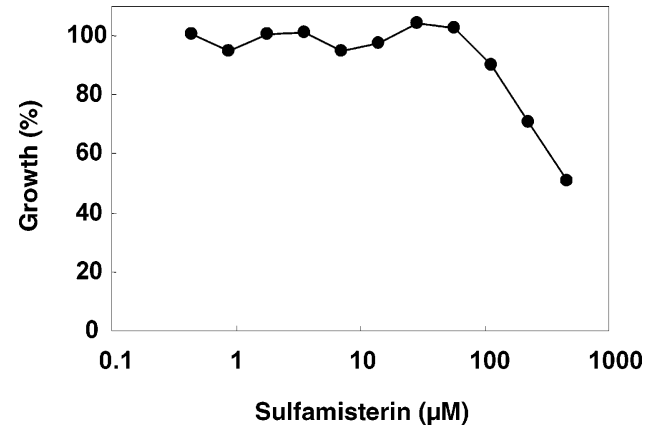

FIGURE 5: Effect of sulfamisterin on cell growth. $\mathrm{CHO}$ cells were cultured in the presence or absence of sulfamisterin for 2 days, and cellular proliferation was determined as described under the Experimental Procedures. The number of cells after culture without sulfamisterin corresponds to $100 \%$.

sphingomyelin or its metabolites were supplied from serum when cells were cultured in normal medium. It is also suggested that the inhibitory effect of sulfamisterin on sphingolipid biosynthesis lasted for 3 days. It has to be stressed that although sulfamisterin inhibits sphingolipid biosynthesis very rapidly after the addition, the content of sphingomyelin decreased gradually likely because of the slow turnover of the lipid.

Next, we studied the effect of sulfamisterin on cell growth. $\mathrm{CHO}$ cells were cultured in normal medium in the presence of sulfamisterin for 2 days, and the number of living cells was quantified (Figure 5). Sulfamisterin did not affect cell growth at concentrations up to $100 \mu \mathrm{M}$. Sulfamisterin (100 $\mu \mathrm{M})$ did not affect cell growth even after 3 days, while cell growth was inhibited in a time-dependent manner with 500 $\mu \mathrm{M}$ sulfamisterin (data not shown). At $10 \mu \mathrm{M}$, the concentration required for complete inhibition of sphingolipid biosynthesis, sulfamisterin did not affect cell growth. As shown in Table 1, cells retain $70 \%$ of sphingomyelin even in the presence of $45 \mu \mathrm{M}$ sulfamisterin when cells were grown in normal medium. Our results support the idea that new synthesis of sphingolipids is not essential for cell growth (11).
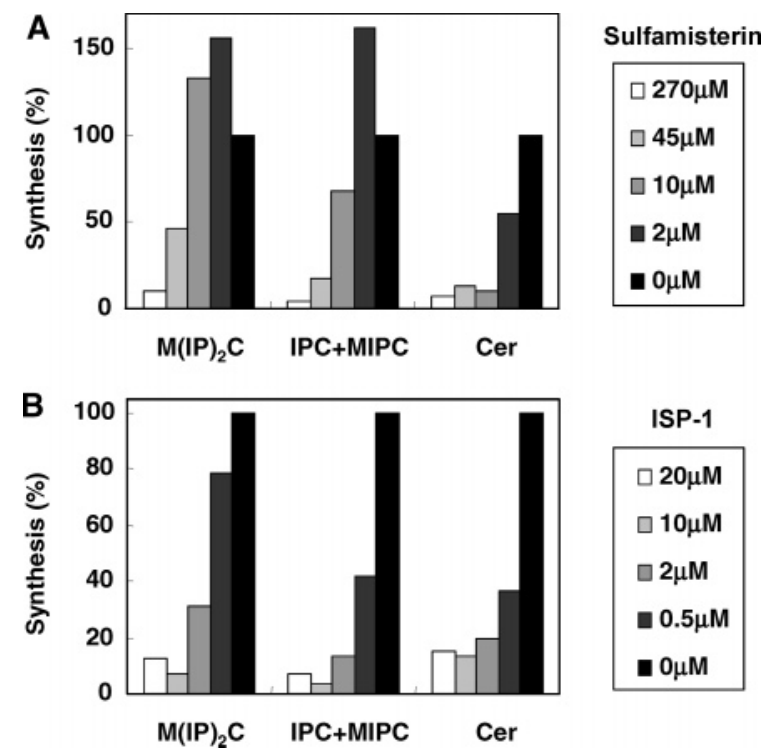

FIGURE 6: Sulfamisterin inhibited sphingolipid biosynthesis in $S$. cerevisiae. KMY1006a strain was treated with sulfamisterin (A) or ISP-1 (B) for $1 \mathrm{~h}$ at the indicated concentrations and then labeled with $\left[{ }^{3} \mathrm{H}\right]$ serine for $3.5 \mathrm{~h}$. Lipids were extracted and separated by TLC, and the pattern of radiolabeled lipids was visualized and quantified as described in the Experimental Procedures. Bars represent the percentage of lipid synthesis against the value when cells were cultured without antibiotics. M(IP) ${ }_{2} \mathrm{C}$, mannosyldiinositol diphosphorylceramide; MIPC, mannnosylinositol phosphorylceramide; IPC, inositol phosphorylceramide; and Cer, phytoceramide.

Sulfamisterin Inhibits Sphingolipid Biosynthesis in S. cerevisiae. Mammalian and yeast cells share biosynthetic pathways for sphingolipids up to the formation of dihydrosphingosine (4). In yeast, after dihydrosphingosine formation, phytoceramide gives rise mostly to inositol-containing sphingolipids: inositol phosphorylceramide (IPC), mannosylinositol phosphorylceramide (MIPC), and mannosyldiinositol diphosphorylceramide (M(IP) $\left.)_{2} \mathrm{C}\right)$. Using $\left[{ }^{3} \mathrm{H}\right]$ serine as a precursor, the effect of sulfamisterin and ISP-1 on sphingolipid synthesis in S. cerevisiae strain KMY1006a was 

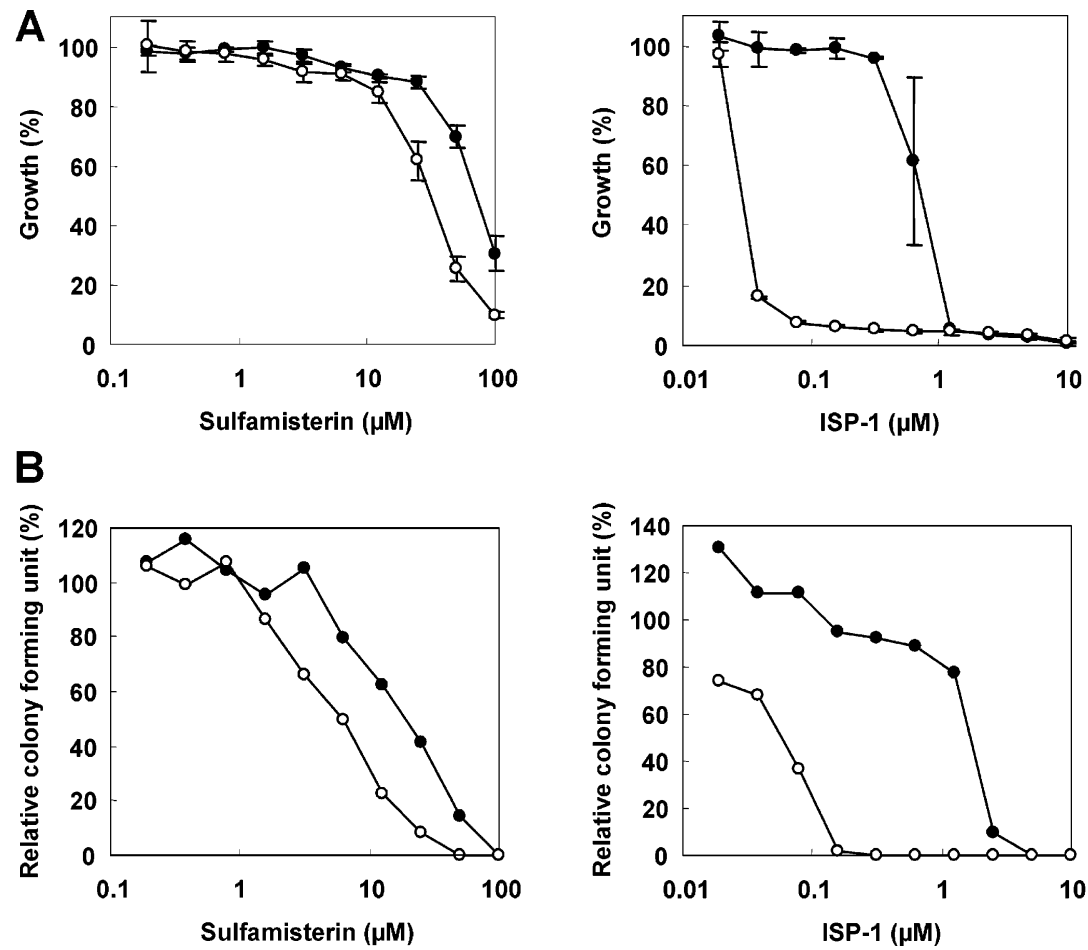

FIGURE 7: Growth inhibition of $S$. cerevisiae by sulfamisterin and ISP-1. (A) BY4741 strain ( $($ ) or $\Delta$ slil mutant (O) was cultured in the presence or absence of inhibitors for $48 \mathrm{~h}$, and the cell growth was evaluated as described under the Experimental Procedures. The data show the mean values \pm standard deviation from three independent experiments. (B) Colony-forming assay was performed after one series of the experiment in A. - BY4741; and $\bigcirc, \Delta$ slil mutant. The number of colonies after culture without inhibitors corresponds to $100 \%$.
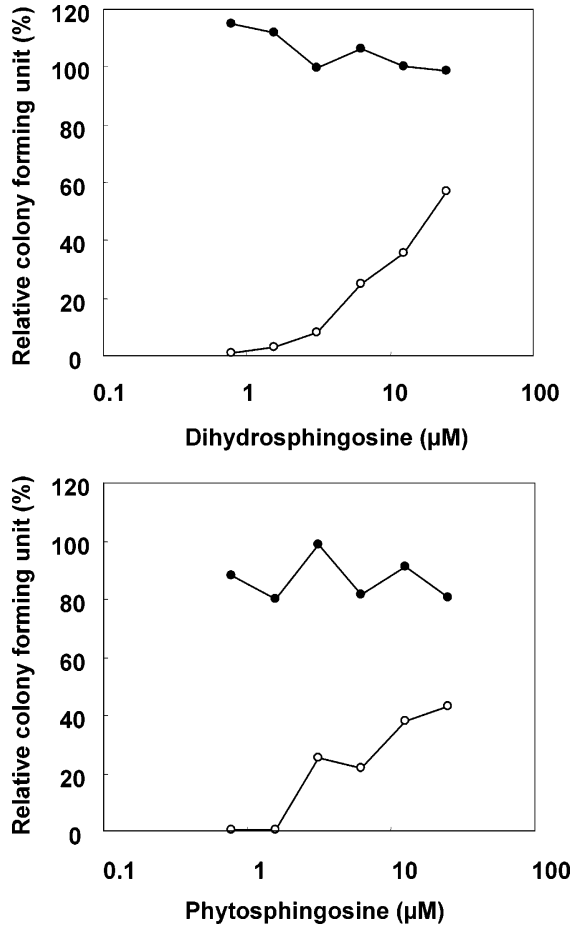

FIGURE 8: Sphingolipid biosynthesis intermediates rescued the growth inhibition of $S$. cerevisiae induced by sulfamisterin. Yeast strain BY4741 was cultured for $48 \mathrm{~h}$ with $0 \mu \mathrm{M}(0)$ or $100 \mu \mathrm{M}$ (O) sulfamisterin in the presence of dihydrosphingosine or phytosphingosine. Then, the colony-forming assay was performed as described under the Experimental Procedures. The number of colonies without sulfamisterin and sphingolipid biosynthesis intermediates corresponds to $100 \%$.

studied. While $50 \mathrm{nM}$ ISP-1 was sufficient to inhibit sphingolipid biosynthesis in mammalian cells (parts A and B of Figure 4), $2 \mu \mathrm{M}$ ISP-1 was required for $50 \%$ inhibition
Table 2: Inhibition of SPT Activity by Sulfamisterin and Its Analogues in Cell-Free Lysate ${ }^{a}$

\begin{tabular}{lccc}
\hline compound & $\mathrm{IC}_{50}(\mathrm{nM})$ & compound & $\mathrm{IC}_{50}(\mathrm{nM})$ \\
\hline sulfamisterin & 7.8 & derivative 3 & 3.5 \\
derivative 1 & 5.4 & derivative 4 & 3.2 \\
derivative 2 & 30.0 & derivative 7 & 17.0 \\
\hline
\end{tabular}

${ }^{a}$ The activity of SPT in CHO lysate was measured in the presence of sulfamisterin or its structural analogues as in Figure 3 . $\mathrm{IC}_{50}$ values for inhibition were calculated from three independent experiments.

of sphingolipid synthesis in yeast (Figure 6B). This difference is perhaps due to the fact that ISP-1 is inactivated through the conversion to $N$-acetyl-ISP-1 by Sli1p in yeast (15). Sulfamisterin inhibited biosynthesis of phytoceramide, IPC, and MIPC in yeast with an $\mathrm{IC}_{50} \approx 10 \mu \mathrm{M}$ (Figure 6A). This concentration is comparable to that required for the inhibition of sphingolipid synthesis in mammalian cells (Figure 4C). Similar results were obtained when another yeast strain BY4741 was used (data not shown). These results suggest that sulfamisterin is not $N$-acetylated by Sli1p. To confirm this, we performed the growth inhibition assay using yeast strain BY4741 (wild-type parent cells) and the $\Delta$ slil mutant. In Figure 7A, the number of cells was estimated after culture in the presence of sulfamisterin or ISP-1 for 2 days. Successively, the colony-forming assay was performed to evaluate the proliferating cells (Figure 7B). As reported, the $\Delta$ sli1 mutant was more susceptible to ISP-1 than the wildtype strain because of the lack of Sli1p (15). In contrast, sulfamisterin almost equally affected the growth of these two strains.

We then asked whether the toxicity of sulfamisterin on $S$. cerevisiae was rescued by supplying sphingolipid biosynthesis intermediates, such as dihydrosphingosine or phytosphingosine. As shown in Figure 8, sphingolipid intermedi- 
Table 3: Inhibition of Sphingolipid Biosynthesis by Sulfamisterin and Its Analogues ${ }^{a}$

\begin{tabular}{|c|c|c|c|c|c|c|c|c|}
\hline \multirow[b]{2}{*}{ compound } & \multicolumn{2}{|c|}{ SM } & \multicolumn{2}{|c|}{ GlcCer } & \multicolumn{2}{|c|}{ Cer } & \multicolumn{2}{|c|}{ PS } \\
\hline & $10 \mu \mathrm{M}$ & $2 \mu \mathrm{M}$ & $10 \mu \mathrm{M}$ & $2 \mu \mathrm{M}$ & $10 \mu \mathrm{M}$ & $2 \mu \mathrm{M}$ & $10 \mu \mathrm{M}$ & $2 \mu \mathrm{M}$ \\
\hline sulfamisterin & 5.9 & 41.7 & 0.0 & 8.8 & 0.0 & 5.8 & 71.0 & 107.7 \\
\hline derivative 1 & 7.1 & 49.9 & 0.0 & 12.9 & 0.0 & 6.3 & 77.3 & 110.6 \\
\hline derivative 2 & 27.6 & 122.9 & 1.5 & 133.6 & 2.0 & 126.3 & 90.3 & 120.2 \\
\hline derivative 3 & 9.2 & 126.7 & 1.6 & 144.4 & 1.5 & 138.5 & 91.5 & 121.1 \\
\hline derivative 4 & 8.1 & 127.2 & 2.0 & 138.3 & 0.1 & 131.8 & 98.9 & 118.3 \\
\hline derivative 7 & 29.4 & 96.0 & 14.9 & 99.7 & 6.6 & 100.7 & 92.5 & 95.3 \\
\hline
\end{tabular}

${ }^{a} \mathrm{CHO}$ cells were treated with sulfamisterin or its structural derivatives overnight at 10 or $2 \mu \mathrm{M}$. Then, cells were labeled with $\left[{ }^{14} \mathrm{C}\right]$ serine for $2 \mathrm{~h}$. Newly synthesized lipids were analyzed by TLC as described in the Experimental Procedures. The synthesis without inhibitors corresponds to 100\%. SM, sphingomyelin; GlcCer, glucosylceramide; Cer, ceramide; and PS, phosphatidylserine.

ates themselves did not affect the growth of yeast at the concentrations that we used (@). However, both dihydrosphingosine and phytosphingosine rescued the growth of cells in a dose-dependent manner $(\bigcirc)$. These results indicate that the toxicity of sulfamisterin is due to inhibition of the early steps of sphingolipid synthesis.

Inhibition of SPT Activity by Structural Analogues of Sulfamisterin. To obtain insights into the structure-activity relationship of sulfamisterin, we chemically synthesized several structural analogues of sulfamisterin (Figure 2) and examined their activities. In Table 2, SPT activity in CHO lysate was measured in the presence of various derivatives as well as sulfamisterin and $\mathrm{IC}_{50}$ values for inhibition were calculated. In addition to sulfamisterin, all structural analogues inhibited SPT activity in a cell-free system. Derivatives 3 and 4 inhibited SPT activity at lower concentration than sulfamisterin, while derivatives 2 and 7 were less effective than sulfamisterin.

Next, we compared the inhibitory effect of sulfamisterin and its structural analogues on sphingolipid biosynthesis (Table 3). Above $10 \mu \mathrm{M}$, all compounds markedly inhibited the biosynthesis of sphingomyelin, glucosylceramide, and ceramide in CHO cells. At $2 \mu \mathrm{M}$, derivatives $2,3,4$, and 7 did not inhibit sphingolipid synthesis, while sulfamisterin and derivative 1 did. At $0.4 \mu \mathrm{M}$, all compounds did not significantly show inhibitory activity (data not shown). Biosynthesis of phosphatidylserine and phosphatidylethanolamine was not inhibited by all compounds at any concentrations. Although derivatives 3 and 4 inhibited SPT activity at lower concentration than sulfamisterin in a cell-free system (Table 2), they were less effective than sulfamisterin in intact cells.

The structural differences between sulfamisterin and ISP-1 are the (1) absence of the double bond at $\mathrm{C} 4-\mathrm{C} 5$ in sulfamisterin, (2) absence of the hydroxyl group at $\mathrm{C} 4$ in sulfamisterin, (3) presence of the sulfate group at C3 in sulfamisterin instead of the hydroxyl group in ISP-1, and 4) length of hydrocarbon chain. In a cell-free system, sulfamisterin was 10 times less effective than ISP-1. However, when added to living mammalian cells, sulfamisterin was 200 times less effective than ISP-1. Our results indicated that changing the sulfate group in sulfamisterin to a hydroxyl group, slightly increased the activity in a cell-free system. However, the activity in intact cells was lowered by the introduction of the hydroxyl group, indicating that the sulfate group is not responsible for the difference between the observed activities of sulfamisterin and ISP-1. Changing the carbonyl group at
C12 to a hydroxyl or hydroxylamino group did not significantly affect the activity, suggesting that this carbonyl group is not critical for the inhibitory activity.

In conclusion, we have introduced a new inhibitor of SPT. Unlike ISP-1, sulfamisterin worked almost equally in mammals and yeast. Sulfamisterin and its derivatives may become additional tools to study sphingolipid metabolism and its biological roles in various eukaryotic cells.

\section{ACKNOWLEDGMENT}

We thank Dr. Y. Kozutsumi and Dr. M. Momoi (RIKEN Frontier, Kyoto University) for generously providing yeast strains and for helpful discussions. We are grateful to $\mathrm{K}$. Iwamoto, A. Makino, R. Ishitsuka, H. Shogomori, M. Takahashi, and F. Hullin-Matsuda for critically reading the manuscript.

\section{REFERENCES}

1. Hannun, Y. A., and Luberto, C. (2000) Ceramide in the eukaryotic stress response, Trends Cell Biol. 10, 73-80.

2. Mathias, S., Pena, L. A., and Kolesnick, R. N. (1998) Signal transduction of stress via ceramide, Biochem. J. 335, 465-480.

3. Spiegel, S., and Merrill, A. H., Jr. (1996) Sphingolipid metabolism and cell growth regulation, FASEB J. 10, 1388-1397.

4. Dickson, R. C. (1998) Sphingolipid functions in Saccharomyces cerevisiae: Comparison to mammals, Ann. Rev. Biochem. 67, 2748.

5. Merrill, A. H., Jr. (2002) De novo sphingolipid biosynthesis: A necessary, but dangerous, pathway, J. Biol. Chem. 277, 2584325846.

6. Hanada, K. (2003) Serine palmitoyltransferase, a key enzyme of sphingolipid metabolism, Biochim. Biophys. Acta 1632, 16-30.

7. Yasuda, S., Nishijima, M., and Hanada, K. (2003) Localization, topology, and function of the LCB1 subunit of serine palmitoyltransferase in mammalian cells, J. Biol. Chem. 278, 4176-4183.

8. Buede, R., Rinker-Schaffer, C., Pinto, W. J., Lester, R. L., and Dickson, R. C. (1991) Cloning and characterization of LCB1, a Saccharomyces gene required for biosynthesis of the long-chain base component of sphingolipids [erratum appears in J. Bacteriol. (1993) Feb, 175 (3), 919], J. Bacteriol. 173, 4325-4332.

9. Pinto, W. J., Srinivasan, B., Shepherd, S., Schmidt, A., Dickson, R. C., and Lester, R. L. (1992) Sphingolipid long-chain-base auxotrophs of Saccharomyces cerevisiae: Genetics, physiology, and a method for their selection, J. Bacteriol. 174, 2565-2574.

10. Nagiec, M. M., Baltisberger, J. A., Wells, G. B., Lester, R. L., and Dickson, R. C. (1994) The LCB2 gene of Saccharomyces and the related LCB1 gene encode subunits of serine palmitoyltransferase, the initial enzyme in sphingolipid synthesis, Proc. Natl. Acad. Sci. U.S.A. 91, 7899-7902.

11. Hanada, K., Nishijima, M., Kiso, M., Hasegawa, A., Fujita, S., Ogawa, T., and Akamatsu, Y. (1992) Sphingolipids are essential for the growth of Chinese hamster ovary cells. Restoration of the growth of a mutant defective in sphingoid base biosynthesis by exogenous sphingolipids, J. Biol. Chem. 267, 23527-23533. 
12. Perry, D. K. (2002) Serine palmitoyltransferase: role in apoptotic de novo ceramide synthesis and other stress responses, Biochim. Biophys. Acta 1585, 146-152.

13. Miyake, Y., Kozutsumi, Y., Nakamura, S., Fujita, T., and Kawasaki, T. (1995) Serine palmitoyltransferase is the primary target of a sphingosine-like immunosuppressant, ISP-1/myriocin, Biochem. Biophys. Res. Commun. 211, 396-403.

14. Sun, Y., Taniguchi, R., Tanoue, D., Yamaji, T., Takematsu, H., Mori, K., Fujita, T., Kawasaki, T., and Kozutsumi, Y. (2000) Sli2 (Ypk1), a homologue of mammalian protein kinase SGK, is a downstream kinase in the sphingolipid-mediated signaling pathway of yeast, Mol. Cell. Biol. 20, 4411-4419.

15. Momoi, M., Tanoue, D., Sun, Y., Takematsu, H., Suzuki, Y., Suzuki, M., Suzuki, A., Fujita, T., and Kozutsumi, Y. (2004) SLI1 (YGR212W) is a major gene conferring resistance to sphingolipid biosynthesis inhibitor ISP-1, and encodes an ISP-1 $N$-acetyltransferase in yeast, Biochem. J. 381, 321-328.

16. Nakamura, S., Kozutsumi, Y., Sun, Y., Miyake, Y., Fujita, T., and Kawasaki, T. (1996) Dual roles of sphingolipids in signaling of the escape from and onset of apoptosis in a mouse cytotoxic T-cell line, CTLL-2, J. Biol. Chem. 271, 1255-1257.

17. Fujita, T., Inoue, K., Yamamoto, S., Ikumoto, T., Sasaki, S., Toyama, R., Chiba, K., Hoshino, Y., and Okumoto, T. (1994) Fungal metabolites. Part 11. A potent immunosuppressive activity found in Isaria sinclairii metabolite, J. Antibiot. 47, 208-215.

18. Horn, W. S., Smith, J. L., Bills, G. F., Raghoobar, S. L., Helms, G. L., Kurtz, M. B., Marrinan, J. A., Frommer, B. R., Thornton, R. A., and Mandala, S. M. (1992) Sphingofungins E and F: Novel serinepalmitoyl transferase inhibitors from Paecilomyces variotii, J. Antibiot. 45, 1692-1696.

19. Zweerink, M. M., Edison, A. M., Wells, G. B., Pinto, W., and Lester, R. L. (1992) Characterization of a novel, potent, and specific inhibitor of serine palmitoyltransferase, J. Biol. Chem. 267, 25032-25038.

20. Mandala, S. M., Frommer, B. R., Thornton, R. A., Kurtz, M. B., Young, N. M., Cabello, M. A., Genilloud, O., Liesch, J. M., Smith, J. L., and Horn, W. S. (1994) Inhibition of serine palmitoyltransferase activity by lipoxamycin, J. Antibiot. 47, 376-379.
21. Mandala, S. M., Thornton, R. A., Frommer, B. R., Dreikorn, S., and Kurtz, M. B. (1997) Viridiofungins, novel inhibitors of sphingolipid synthesis, J. Antibiot. 50, 339-343.

22. Onishi, J. C., Milligan, J. A., Basilio, A., Bergstrom, J., Curotto, J., Huang, L., Meinz, M., Nallin-Omstead, M., Pelaez, F., Rew, D., Salvatore, M., Thompson, J., Vicente, F., and Kurtz, M. B. (1997) Antimicrobial activity of viridiofungins, J. Antibiot. 50, 334-338.

23. Sundaram, K. S., and Lev, M. (1984) Inhibition of sphingolipid synthesis by cycloserine in vitro and in vivo, J. Neurochem. 42, 577-581.

24. Medlock, K. A., and Merrill, A. H., Jr. (1988) Inhibition of serine palmitoyltransferase in vitro and long-chain base biosynthesis in intact Chinese hamster ovary cells by $\beta$-chloroalanine, Biochemistry 27, 7079-7084.

25. Merrill, A. H., Jr. (1983) Characterization of serine palmitoyltransferase activity in Chinese hamster ovary cells, Biochim. Biophys. Acta 754, 284-291.

26. Bligh, E. G., and Dyer, W. (1959) A rapid method of total lipid extraction and purification, Can. J. Biochem. Physiol. 37, 911918.

27. Chalvardjian, A., and Rudnicki, E. (1970) Determination of lipid phosphorus in the nanomolar range, Anal. Biochem. 36, 225226.

28. Merrill, A. H., Jr., Liotta, D. C., and Riley, R. T. (1996) Fumonisins: Fungal toxins that shed light on sphingolipid function, Trends Cell Biol. 6, 218-223.

29. Inokuchi, J., and Radin, N. S. (1987) Preparation of the active isomer of 1-phenyl-2-decanoylamino-3-morpholino-1-propanol, inhibitor of murine glucocerebroside synthetase, J. Lipid Res. 28, $565-571$

30. Merrill, A. H., Jr., and Jones, D. D. (1990) An update of the enzymology and regulation of sphingomyelin metabolism, Biochim. Biophys. Acta 1044, 1-12.

31. Tijburg, L. B., Geelen, M. J., and van Golde, L. M. (1989) Regulation of the biosynthesis of triacylglycerol, phosphatidylcholine, and phosphatidylethanolamine in the liver, Biochim. Biophys. Acta 1004, 1-19.

BI048605L 